\title{
Optimasi Konsentrasi Asetosiringon dan Higromisin dalam Transformasi Genetik Padi Fatmawati dengan Perantaraan Agrobacterium tumefaciens
}

\author{
Optimation of Acetosyringone and Hygromycin on Genetic Transformation \\ of Rice cv. Fatmawati Mediated by Agrobacterium tumefaciens
}

\author{
Atmitri Sisharmini ${ }^{1,2}$, Bambang Sapta Purwoko ${ }^{3 *}$, Nurul Khumaida ${ }^{3}$, dan Kurniawan Rudi Trijatmiko ${ }^{2}$ \\ ${ }^{1}$ Program Studi Pemuliaan dan Bioteknologi Tanaman, Sekolah Pascasarjana, Institut Pertanian Bogor \\ ${ }^{2}$ Balai Besar Penelitian dan Pengembangan Bioteknologi dan \\ Sumberdaya Genetik Pertanian, Jl. Tentara Pelajar No. 3A, Bogor 16111 \\ ${ }^{3}$ Departemen Agronomi dan Hortikultura, Fakultas Pertanian, Institut Pertanian Bogor \\ (Bogor Agricultural University), Jl. Meranti, Kampus IPB Darmaga, Bogor 16680, Indonesia
}

Diterima 9 Januari 2018/Disetujui 10 Agustus 2018

\begin{abstract}
Protocols for genetic transformation of rice have been widely developed, however the protocols are not universal and inapplicable for all types of rice plants directly. Transformation protocol on rice cv. Fatmawati needs to be developed to generate transgenic lines. The present research was carried out to optimize genetic transformation protocol in rice cv. Fatmawati mediated by Agrobacterium tumefaciens harboring pCambia1301 construct using immature embryo as an explant. The experiment was arranged in a completely randomized design. Factors influencing efficiency of transformation, i.e., sensitivity of callus to hygromycin antibiotic, acetosyringone concentration used in cultivation medium, hygromycin concentration for transformant selection were optimized. The results showed that genetic transformation of rice cv. Fatmawati mediated by A. tumefaciens using immature embryos have been successfully carried out with several parameters. Addition of $100 \mu \mathrm{M}$ acetosyringone in co-cultivation medium and $30 \mathrm{mg} \mathrm{L^{-1 }}$ hygromycin for transformant callus selection were optimal for genetic transformation of rice $c v$. Fatmawati mediated by A. tumefaciens. Transformation efficiency was found to be $7.84 \%$ based on the lines carrying the hpt gene. This result would be a valuable reference in genetic transformation of rice cv. Fatmawati using target genes.
\end{abstract}

Keywords: immature embryo, Oryza sativa, pCambia1301, transformation efficiency

\section{ABSTRAK}

Protokol transformasi genetik tanaman padi telah banyak dihasilkan, namun protokol tersebut bersifat tidak universal dan tidak dapat diadopsi untuk semua jenis tanaman padi secara langsung. Studi transformasi pada padi Fatmawati perlu dipelajari untuk memperbesar peluang didapatkannya tanaman transgenik. Eksplan embrio muda merupakan eksplan yang paling responsif untuk ditransformasi. Penelitian ini dilakukan untuk mengoptimasi metode transformasi genetik padi Fatmawati yang dimediasi Agrobacterium tumefaciens yang membawa plasmid pCambia1301 dengan menggunakan embrio muda sebagai eksplan. Rancangan percobaan menggunakan rancangan acak lengkap. Faktor yang mempengaruhi efisiensi transformasi pada padi yaitu tingkat kepekaan kalus padi terhadap higromisin, konsentrasi asetosiringon yang digunakan dalam media kokultivasi, dan konsentrasi antibiotik higromisin untuk seleksi kalus transforman dioptimasi. Hasil penelitian menunjukkan bahwa transformasi genetik padi Fatmawati yang dimediasi dengan Agrobacterium tumefaciens menggunakan eksplan embrio muda telah berhasil dilakukan dengan beberapa parameter. Penggunaan senyawa asetosiringon $100 \mu M$ pada media kokultivasi dan antibiotik higromisin $30 \mathrm{mg} \mathrm{L}^{-1}$ untuk menyeleksi kalus transforman merupakan konsentrasi yang

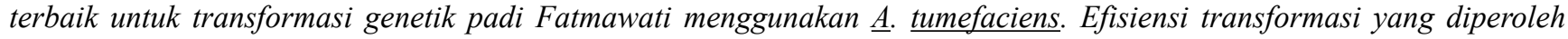
adalah sebesar $7.84 \%$ yang didasarkan pada galur yang positif mengandung gen hpt. Hasil penelitian ini dapat menjadi acuan dalam transformasi genetik padi Fatmawati menggunakan gen target.

Kata kunci: efisiensi transformasi, embrio muda, Oryza sativa, pCambia1301

\footnotetext{
* Penulis untuk korespondensi. e-mail: bspurwoko@apps.ipb.ac.id
} 


\section{PENDAHULUAN}

Rekayasa genetik tanaman telah menjadi salah satu strategi penting dalam pemuliaan tanaman modern berbasis bioteknologi. Produksi tanaman transgenik merupakan proses rutin yang telah dilakukan dan diterapkan pada beberapa spesies tanaman. Gen-gen yang diintroduksikan ke tanaman menyandikan sifat-sifat penting seperti perbaikan kualitas tanaman, ketahanan terhadap hama dan penyakit. Upaya perbaikan dalam mengembangkan metode transformasi yang baru dan lebih efisien sudah banyak dilakukan (Ozawa, 2009; Saika dan Toki, 2010; Sahoo et al., 2011; Cho et al., 2015).

Regenerasi tunas transforman merupakan kendala utama dalam transformasi genetik padi sehingga memerlukan sistem kultur jaringan yang efisien dan optimal (Sahoo et al., 2011). Ketersediaan jaringan target yang kompeten, metode introduksi DNA ke dalam sel, prosedur dalam menyeleksi dan meregenerasikan sel-sel transforman merupakan faktor-faktor yang penting dalam sistem transformasi (Sah et al., 2014). Kombinasi antara protokol regenerasi dan transformasi yang tepat dan optimal akan menentukan keberhasilan mendapatkan tanaman padi transgenik. Protokol regenerasi dan transformasi genetik tanaman padi telah banyak dihasilkan, namun protokol tersebut bersifat tidak universal dan tidak dapat diadopsi untuk semua jenis tanaman padi secara langsung (Hiei dan Komari, 2008; Tie et al., 2012). Kemampuan regenerasi dan efisiensi transformasi genetik pada padi dipengaruhi oleh genotipe, umur dan jenis eksplan, media dasar, kombinasi hormon tumbuh, periode dan kondisi kultur (Sahoo dan Tuteja, 2012; Vennapusa et al., 2015). Oleh karena kemampuan regenerasi tanaman dipengaruhi genotipe, sehingga kadang-kadang memerlukan manipulasi in vitro yang berbeda untuk genotipe yang berbeda. Metode kultur jaringan dari sel-sel non transforman merupakan syarat utama didapatkannya protokol transformasi yang efisien, sehingga dapat digunakan sebagai acuan dalam optimasi transformasi genetik tanaman (Hiei et al., 2014).

Diantara teknologi transformasi genetik lainnya, transformasi yang dimediasi oleh Agrobacterium lebih banyak dipilih karena tekniknya relatif lebih mudah dan murah. Sistem transformasi padi yang dimediasi Agrobacterium tumefaciens merupakan transformasi yang paling umum digunakan, karena mempunyai jumlah salinan gen yang relatif rendah dan stabil dengan sedikit pengaturan kembali jika dibandingkan dengan metode transfer DNA secara langsung seperti penembakan partikel (Nyaboga et al., 2014). Embrio muda merupakan eksplan yang mempunyai kompetensi regenerasi dan efisiensi yang tinggi dalam transformasi padi (Hiei dan Komari, 2008).

Fatmawati merupakan varietas padi unggul tipe baru yang dilepas oleh Balitbangtan pada tahun 2003. Karakteristik padi Fatmawati adalah mempunyai hasil tinggi sekitar 7.5 ton $\mathrm{ha}^{-1}$. Agak tahan terhadap wereng coklat biotipe 2 dan 3, tahan terhadap hawar daun bakteri strain III dan agak tahan terhadap strain IV. Kelemahan padi Fatmawati adalah tidak tahan blas dan mempunyai sterilitas spikelet yang tinggi ( $\geq 50 \%$ gabah hampa) (Abdullah et al.,
2008). Pengembangan padi ini menjadi varietas baru dengan karakter-karakter yang lebih unggul mempunyai potensi yang sangat tinggi melalui rekayasa genetik.

Tujuan penelitian ini adalah mendapatkan metode transformasi tanaman padi Fatmawati dengan menggunakan embrio muda sebagai eksplan. Beberapa faktor yang mempengaruhi efisiensi transformasi dipelajari dalam transformasi padi Fatmawati, yaitu mengenai pengujian tingkat kepekaan kalus padi terhadap higromisin, konsentrasi asetosiringon yang digunakan dalam media kokultivasi dan konsentrasi higromisin minimal untuk seleksi kalus transforman. Dengan mempelajari faktorfaktor yang mempengaruhi transformasi diharapkan kondisi transformasi yang optimal untuk padi Fatmawati dapat diperoleh sehingga protokol ini dapat digunakan untuk transformasi selanjutnya dengan menggunakan gen target.

\section{BAHAN DAN METODE}

\section{Penyiapan Eksplan}

PenelitiandilakukandilaboratoriumBiologiMolekuler, Balai Besar Penelitian dan Pengembangan Bioteknologi dan Sumberdaya Genetik Pertanian pada tahun 2016. Bahan penelitian yang digunakan adalah Agrobacterium tumefaciens strain LBA4404 yang mengandung konstruk pCAMBIA1301 dan tanaman padi varietas Fatmawati sebagai sumber eksplan. Metode transformasi yang digunakan dalam penelitian ini mengacu pada protokol Slamet-Loedin et al. (2014) dengan menggunakan embrio muda sebagai eksplan (Gambar 1).

Embrio muda diisolasi dari biji-biji muda padi(berumur 8-12 hari setelah pembungaan) yang telah dibuang kulit gabahnya dan disterilisasi dengan 70\% ethanol selama 5-10 detik dan larutan 1\% sodium hypochlorite selama 5 menit. Embrio muda diisolasi dari biji menggunakan pinset.

\section{Pengujian Tingkat Kepekaan Kalus Padi Fatmawati terhadap Higromisin}

Percobaan pendahuluan dilakukan untuk menguji tingkat kepekaan kalus terhadap higromisin. Bahan berupa kalus yang berumur 7 hari yang ditumbuhkan pada media induksi kalus. Media induksi kalus yang digunakan adalah media dasar makro N6 (Chu et al., 1975) dengan penambahan mikro B5 dan vitamin B5 (Gamborg et al., 1968), casamino acid $500 \mathrm{mg} \mathrm{L}^{-1}$, L-prolin $500 \mathrm{mg} \mathrm{L}^{-1}$, sukrosa $30 \mathrm{~g} \mathrm{~L}^{-1}, 2.4-\mathrm{D} 2 \mathrm{mg} \mathrm{L}^{-1}$, BAP $1 \mathrm{mg} \mathrm{L}^{-1}$ dan NAA $2 \mathrm{mg} \mathrm{L}^{-1}$. Kalus yang berumur 7 hari diseleksi pada media seleksi yaitu media induksi kalus yang ditambah dengan antibiotik higromisin.

Rancangan percobaan yang digunakan adalah rancangan acak lengkap. Perlakuan yang diberikan adalah perbedaan konsentrasi higromisin yang ditambahkan pada media induksi kalus yaitu $0,10,20,30,40$, dan $50 \mathrm{mg} \mathrm{L}^{-1}$. Jumlah kalus yang diuji adalah 20 kalus untuk masingmasing perlakuan dengan empat ulangan. Data persentase kalus hidup pada media seleksi diuji menggunakan sidik ragam. Perbedaan antar perlakuan ditentukan dengan uji 


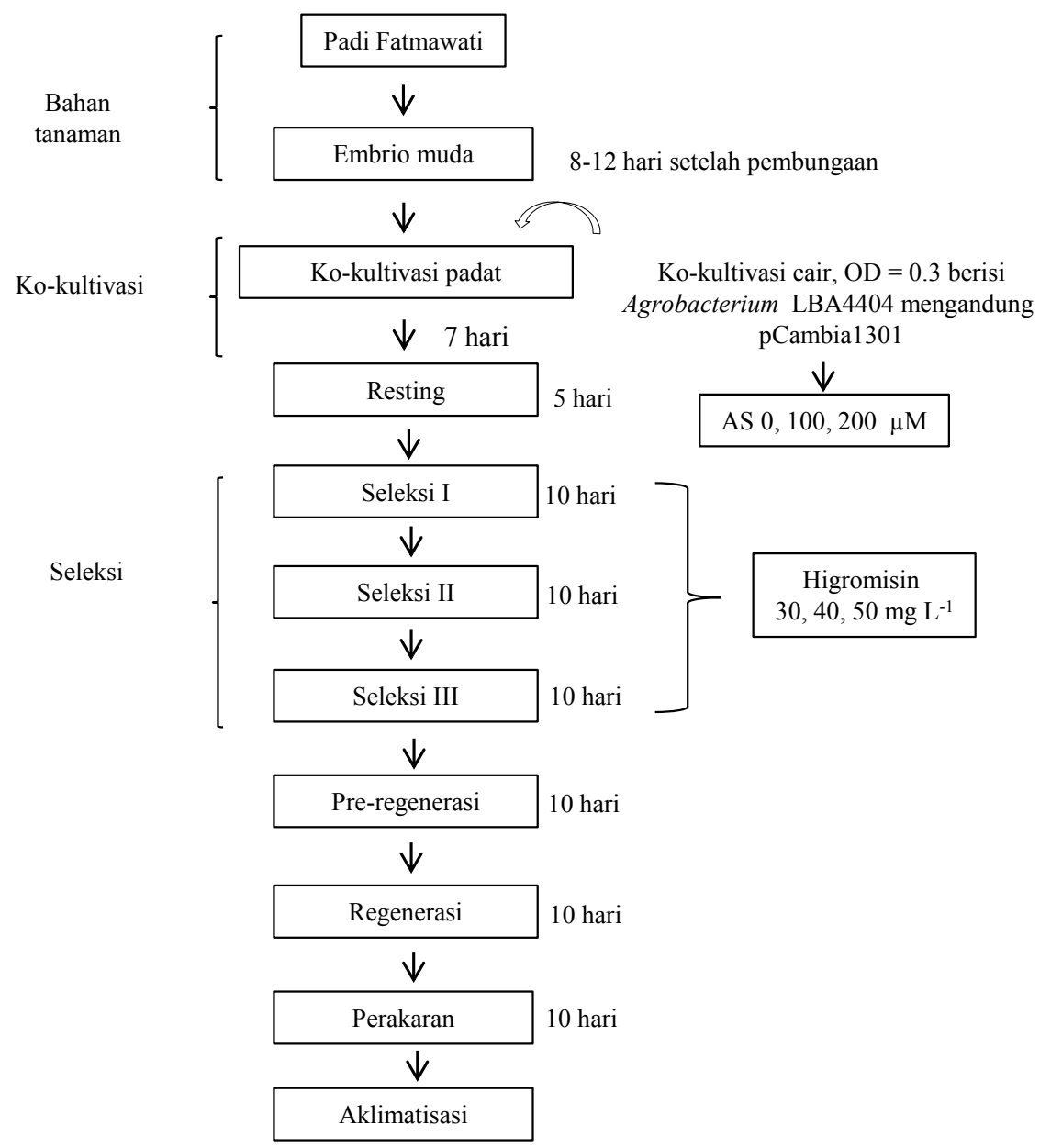

Gambar 1. Bagan tahapan metode transformasi padi Fatmawati dengan perantaraan Agrobacterium tumefaciens

beda nyata terkecil pada taraf uji 0.01 . Analisis statistik menggunakan program $\mathrm{R}$ versi 3.0.1.

Pengamatan dilakukan setelah kalus berumur 3 minggu di media seleksi. Kalus yang berwarna coklat kehitaman menunjukkan adanya penghambatan pertumbuhan kalus. Kalus hidup ditunjukkan dengan warna kalus putih kekuningan dan masih segar. Persentase kalus hidup dihitung dari jumlah kalus yang hidup dibagi dengan jumlah kalus yang ditanam pada media seleksi dan dikalikan 100\%. Kisaran konsentrasi higromisin terpilih digunakan untuk menyeleksi kalus-kalus pada transformasi padi Fatmawati.

\section{Pengaruh Perbedaan Konsentrasi Asetosiringon pada Transformasi Padi Fatmawati}

Transformasi genetik padi Fatmawati dilakukan dengan cara menetesi eksplan embrio muda yang diletakkan pada media ko-kultivasi padat dengan $5 \mu \mathrm{l}$ media ko-kultivasi cair yang berisi kultur Agrobacterium. Bakteri Agrobacterium tumefaciens sebelumnya ditumbuhkan selama 3 hari pada media AB (Chilton et al., 1974) dengan penambahan 50 mg L ${ }^{-1}$ kanamisin pada suhu $28^{\circ} \mathrm{C}$. Kultur bakteri di media $\mathrm{AB}$ dipanen dan ditumbuhkan pada media ko-kultivasi cair. Suspensi ini yang digunakan untuk infeksi embrio muda padi. Perlakuan yang diberikan adalah penambahan asetosiringon (AS) pada media ko-kultivasi cair dan padat (Tabel 1) dengan perlakuan tanpa AS (0), 100, dan $200 \mu \mathrm{M}$ AS dan kerapatan bakteri pada $\mathrm{OD}=0.3$. Embrio yang telah diinfeksi bakteri diinkubasi dalam kondisi gelap pada suhu $25^{\circ} \mathrm{C}$ selama 7 hari dan selanjutnya dikulturkan pada media resting (Tabel 1). Eksplan dipindahkan ke media seleksi tahap pertama (Tabel 1) dan dikulturkan selama 10 hari dengan 3 kali periode subkultur. Kalus-kalus tahan dipindahkan ke media pre-regenerasi (Tabel 1) dan diinkubasi selama 10 hari. Kalus-kalus yang berproliferasi dengan spot hijau dikulturkan pada media regenerasi yang mengandung $30 \mathrm{mg} \mathrm{L}^{-1}$ higromisin dan $250 \mathrm{mg} \mathrm{L}^{-1}$ cefotaksim. Tunas yang muncul dikulturkan pada media perakaran yang mengandung $40 \mathrm{mg} \mathrm{L}^{-1}$ (Gambar 2). Planlet yang terbentuk selanjutnya diaklimatisasi dan dipindahkan ke pot berisi media tanah dan ditumbuhkan sampai panen di rumah kaca.

Rancangan percobaan yang digunakan dalam penelitian ini adalah rancangan acak lengkap. Perlakuan yang diberikan adalah perbedaan konsentrasi asetosiringon yaitu tanpa penambahan AS (0), 100, dan $200 \mu \mathrm{M}$. Jumlah embrio muda yang diuji adalah 32 buah untuk masingmasing perlakuan dengan empat ulangan. Data persentase pembentukan kalus hidup di media induksi di lakukan uji sidik ragam. Perbedaan antar perlakuan ditentukan dengan 
Tabel 1. Komposisi media yang digunakan untuk transformasi genetik padi Fatmawati (Slamet-Loedin et al., 2014)

\begin{tabular}{|c|c|}
\hline Media & Komposisi \\
\hline Kokultivasi cair & $\begin{array}{l}\text { AA dengan penambahan } 876 \mathrm{mg} \mathrm{L}^{-1} \mathrm{~L} \text {-glutamin, } 260 \mathrm{mg} \mathrm{L}-1 \text { aspartic acid, } 174 \mathrm{mg} \mathrm{L}^{-1} \text { arginin, } 0.086 \mathrm{~g} \\
\mathrm{~L}^{-1} \text { glisin, } 500 \mathrm{mg} \mathrm{L}^{-1} \text { casamino acid, } 20 \mathrm{~g} \mathrm{~L}^{-1} \text { sukrosa dan } 10 \mathrm{~g} \mathrm{~L}^{-1} \text { glukosa, } \mathrm{pH} 5.4 .\end{array}$ \\
\hline Kokultivasi padat & $\begin{array}{l}\text { NB dengan penambahan } 500 \mathrm{mg} \mathrm{L}^{-1} \text { casamino acid, } 500 \mathrm{mg} \mathrm{L}^{-1} \mathrm{~L} \text {-prolin, } 20 \mathrm{~g} \mathrm{~L}^{-1} \text { sukrosa, } 10 \mathrm{~g} \mathrm{~L}^{-1} \\
\text { glukosa, } 2 \mathrm{mg} \mathrm{L}^{-1} 2.4-\mathrm{D}, 1 \mathrm{mg} \mathrm{L}^{-1} \mathrm{BAP}, 2 \mathrm{mg} \mathrm{L}^{-1} \mathrm{NAA}, 5.5 \mathrm{~g} \mathrm{~L}^{-1} \text { Agarose tipe I, } \mathrm{pH} 5.4 .\end{array}$ \\
\hline Resting & $\begin{array}{l}\text { NB dengan penambahan } 500 \mathrm{mg} \mathrm{L}^{-1} \text { casamino acid, } 500 \mathrm{mg} \mathrm{L}^{-1} \mathrm{~L}-\text { prolin, } 300 \mathrm{mg} \mathrm{L}^{-1} \text { glutamin, } 36 \mathrm{~g} \mathrm{~L}^{-1} \\
\text { manitol, } 20 \mathrm{~g} \mathrm{~L}^{-1} \text { maltose, } 1 \mathrm{mg} \mathrm{L}^{-1} 2.4-\mathrm{D}, 1 \mathrm{mg} \mathrm{L}^{-1} \mathrm{NAA}, 0.2 \mathrm{mg} \mathrm{L}^{-1} \mathrm{BAP}, 250 \mathrm{mg} \mathrm{L}^{-1} \text { cefotaksim, } 100 \\
\mathrm{mg} \mathrm{L}^{-1} \text { vancomisin, gelrite } 5 \mathrm{~g} \mathrm{~L}^{-1} \text {, pH 5.8. }\end{array}$ \\
\hline Seleksi & Resting $+30 \mathrm{mg} \mathrm{L}^{-1}$ higromisin \\
\hline Pre regenerasi & $\begin{array}{l}\text { MS dengan penambahan } 30 \mathrm{~g} \mathrm{~L}^{-1} \text { maltose, } 20 \mathrm{~g} \mathrm{~L}^{-1} \text { sorbitol, } 10 \mathrm{~g} \mathrm{~L}^{-1} \text { agarose tipe } \mathrm{I}, 2 \mathrm{mg} \mathrm{L}^{-1} \text { kinetin, } 5 \\
\mathrm{mg} \mathrm{L}^{-1} \mathrm{NAA}, 250 \mathrm{mg} \mathrm{L}^{-1} \text { cefotaksim, } 100 \mathrm{mg} \mathrm{L}^{-1} \text { vancomisin, } 30 \mathrm{mg} \mathrm{L}^{-1} \text { higromisin, } \mathrm{pH} 5.8 \text {. }\end{array}$ \\
\hline Regenerasi & $\begin{array}{l}\text { MS dengan penambahan } 30 \mathrm{~g} \mathrm{~L}^{-1} \text { sukrosa, } 2 \mathrm{mg} \mathrm{L}^{-1} \text { kinetin, } 1 \mathrm{mg} \mathrm{L} \mathrm{L}^{-1} \mathrm{NAA}, 250 \mathrm{mg} \mathrm{L}^{-1} \text { cefotaksim, } 100 \\
\mathrm{mg} \mathrm{L}{ }^{-1} \text { vancomisin, } 30 \mathrm{mg} \mathrm{L}^{-1} \text { higromisin, } 3 \mathrm{~g} \mathrm{~L}^{-1} \text { gelrite, } \mathrm{pH} 5.8 .\end{array}$ \\
\hline Perakaran & MS dengan penambahan $30 \mathrm{~g} \mathrm{~L}^{-1}$ sukrosa, $1 \mathrm{mg} \mathrm{L}^{-1} \mathrm{IBA}, 2 \mathrm{~g} \mathrm{~L}^{-1}$ gelrite, $30 \mathrm{mg} \mathrm{L}^{-1}$ higromisin, $\mathrm{pH} 5.8$. \\
\hline
\end{tabular}

Keterangan: AA = media asam amino; NB = media dasar N6 dengan penambahan mikro dan vitamin B5; MS = media dasar Murashige dan Skoog

uji beda nyata terkecil pada taraf uji 0.01 . Analisis statistik menggunakan program $\mathrm{R}$ versi 3.0.1.

Variabel lain yang diamati pada perlakuan ini adalah jumlah embrio muda yang ditransformasi, jumlah kalus yang tumbuh pada media ko-kultivasi padat (persentase dihitung dari jumlah kalus yang tumbuh di media kokultivasi padat dibagi jumlah embrio yang ditransformasi dikalikan 100\%), jumlah kalus yang tahan higromisin (kalus berwarna putih kekuningan) di media seleksi tahap ketiga (persentase dihitung dari jumlah kalus yang tahan higromisin di media seleksi tahap ketiga dibagi dengan jumlah embrio yang ditransformasi kemudian dikalikan $100 \%$ ), jumlah kalus yang tumbuh spot hijau (persentase dihitung dari jumlah kalus yang tumbuh spot hijau dibagi dengan jumlah kalus tahan higromisin di media seleksi ketiga), efisiensi transformasi dan efisiensi regenerasi yang dihitung dengan rumus sebagai berikut:

Efisiensi transformasi $=$

Jumlah event mengandung gen higromisin x 100\%

Jumlah embrio yang ditransformasi

Efisiensi regenerasi $=$ Jumlah kalus yang beregenerasi $\quad \times 100 \%$

Jumlah kalus yang lolos seleksi antibiotik

\section{Pengaruh Konsentrasi Higromisin terhadap Seleksi Kalus} Padi Fatmawati

Perlakuan konsentrasi higromisin untuk menyeleksi kalus transforman terdiri atas tiga taraf konsentrasi yaitu 30, 40, dan $50 \mathrm{mg} \mathrm{L}^{-1}$. Variabel yang diamati meliputi jumlah embrio muda yang ditransformasi, jumlah kalus tahan higromisin (warna kalus putih kekuningan) yang dihitung dari jumlah kalus yang hidup di media seleksi tahap ke tiga, jumlah kalus dengan spot hijau yang dihitung dari jumlah kalus yang muncul spot-spot hijaunya, jumlah kalus beregenerasi yang dihitung dari jumlah kalus yang dapat beregenerasi menghasilkan tunas, efisiensi regenerasi, efisiensi transformasi dan jumlah galur positif PCR yang dihitung dari jumlah galur independen yang positif mengandung gen ketahanan antibiotik hygromicyn phosphotransferase (hpt) ketika dideteksi dengan teknik PCR.

\section{Analisis Molekuler Galur Padi Putatif Transgenik Menggunakan Teknik PCR}

Analisis molekuler dengan PCR dilakukan untuk mendeteksi keberadaan gen pada tanaman padi transforman. Isolasi DNA genom padi dilakukan dengan menggunakan metode CTAB (Murray dan Thompson, 1980). Analisis PCR dilakukan dengan menggunakan sepasang primer spesifik untuk gen marka seleksi hpt (Apriana et al., 2011). Reaksi PCR dilakukan pada volume total 20 ul yang terdiri atas ddH2O, $1 \mathrm{x}$ buffer PCR (10 x), $200 \mu \mathrm{M}$ dNTPs (10mM), $0.25 \mu \mathrm{M}$ primer Forward $(5 \mu \mathrm{M}), 0.25 \mu \mathrm{M}$ primer Reverse $(5 \mu \mathrm{M}), 1 \mathrm{U}$ Taq DNA Pol $\left(5 \mathrm{U} \mu \mathrm{L}^{-1}\right)$, dan cetakan DNA. Program PCR yang digunakan ialah tahap denaturasi awal pada suhu $94{ }^{\circ} \mathrm{C}$ selama 5 menit, kemudian dilanjutkan dengan 35 siklus yang terdiri atas denaturasi pada suhu $94{ }^{\circ} \mathrm{C}$ selama 60 detik, annealing pada suhu $60{ }^{\circ} \mathrm{C}$ selama 45 detik dan elongasi pada suhu $72{ }^{\circ} \mathrm{C}$ selama 60 detik. Hasil PCR kemudian diseparasi pada gel agarose $1 \%$ dengan voltase 100 watt selama 1 jam dan diwarnai dengan ethidium bromida. Pengamatan dilakukan di bawah sinar UV dengan bantuan perangkat chemidoc. Pengamatan hasil PCR berdasarkan ada atau tidaknya pita DNA. PCR memberikan hasil positif jika pita DNA amplikon berukuran sama dengan kontrol plasmid. 


\section{HASIL DAN PEMBAHASAN}

\section{Pengujian Tingkat Kepekaan Kalus Padi terhadap Higromisin}

Gen yang menyandi ketahanan terhadap antibiotik higromisin (hpt) merupakan marka seleksi yang efisien digunakan dalam transformasi padi (Hiei dan Komari, 2008). Tingkat kepekaan kalus terhadap higromisin dilakukan untuk mendapatkan konsentrasi lethal minimum higromisin terhadap kalus transforman. Informasi ini sangat berguna untuk menentukan konsentrasi higromisin yang ditambahkan pada media untuk menyeleksi kalus transforman. Konsentrasi lethal minimum agen seleksi mungkin berbeda di antara genotipe tanaman. Menurut Tran dan Mishra (2015), efektivitas seleksi dengan antibiotik tergantung pada spesies tanaman, kultivar, jenis jaringan, organ maupun perbedaan tahapan perkembangan tanaman pada spesies tanaman yang sama.

Hasil uji tingkat kepekaan kalus yang berasal dari embrio muda padi Fatmawati terhadap antibiotik higromisin menunjukkan bahwa kalus masih mampu tumbuh baik mencapai $100 \%$ dan belum menunjukkan adanya penghambatan pertumbuhan kalus pada perlakuan tanpa higromisin dan $10 \mathrm{mg} \mathrm{L}^{-1}$ higromisin. Kalus sedikit mengalami penghambatan pertumbuhan dengan jumlah kalus yang tahan higromisin sebesar $87.5 \%$ pada konsentrasi $20 \mathrm{mg} \mathrm{L}^{-1}$ higromisin. Pertumbuhan kalus menunjukkan adanya penghambatan sebesar $93.75 \%$ pada konsentrasi $30 \mathrm{mg} \mathrm{L}^{-1}$ higromisin. Penghambatan pertumbuhan kalus $100 \%$ atau tidak ada kalus yang mampu bertahan hidup pada media seleksi ditunjukkan pada konsentrasi $40 \mathrm{mg} \mathrm{L}^{-1}$ dan $50 \mathrm{mg} \mathrm{L}^{-1}$ higromisin (Tabel 2). Hal ini menunjukkan bahwa konsentrasi lethal minimum higromisin pada embrio muda padi Fatmawati terjadi pada konsentrasi $30 \mathrm{mg} \mathrm{L}^{-1}$, karena pada konsentrasi ini sudah mulai menunjukkan penghambatan pertumbuhan kalus dan hanya sekitar $6.25 \%$ kalus yang mampu bertahan hidup. Berdasarkan hasil

Tabel 2. Tingkat ketahanan kalus embrio muda padi Fatmawati tanpa ditransformasi terhadap higromisin

\begin{tabular}{lcc}
\hline $\begin{array}{l}\text { Konsentrasi } \\
\text { higromisin } \\
\left(\mathrm{mg} \mathrm{L}^{-1}\right)\end{array}$ & $\begin{array}{c}\text { Jumlah } \\
\text { kalus yang } \\
\text { diuji }\end{array}$ & $\begin{array}{c}\text { Persentase jumlah kalus } \\
\text { yang hidup pada media } \\
\text { dengan higromisin }(\%)\end{array}$ \\
\hline 0 & 20 & $100.00 \mathrm{a}$ \\
10 & 20 & $100.00 \mathrm{a}$ \\
20 & 20 & $87.50 \mathrm{~b}$ \\
30 & 20 & $6.25 \mathrm{c}$ \\
40 & 20 & $0.00 \mathrm{~d}$ \\
50 & 20 & $0.00 \mathrm{~d}$ \\
\hline
\end{tabular}

Keterangan: Angka pada satu kolom yang dikuti oleh huruf yang sama tidak berbeda pada taraf $1 \%$ menurut uji beda nyata terkecil tersebut, maka konsentrasi higromisin yang dapat digunakan untuk menyeleksi kalus-kalus padi transforman adalah berkisar antara 30-50 $\mathrm{mg} \mathrm{L}^{-1}$. Kalus-kalus yang mempunyai ketahanan terhadap higromisin saja yang nantinya akan mampu bertahan hidup pada media dengan penambahan 30-50 mg L-1 higromisin.

\section{Transformasi dengan Perlakuan Perbedaan Konsentrasi Asetosiringon}

Penambahan asetosiringon pada media ko-kultivasi diperlukan untuk menginduksi gen-gen vir dalam Agrobacterium yang berfungsi untuk memindahkan T-DNA ke dalam sel tanaman dan meningkatkan efisiensi infeksi (Nakano et al., 2017). Konsentrasi asetosiringon yang tepat dapat berfungsi untuk meningkatkan efisiensi transformasi (Jia et al., 2015). Namun, konsentrasi asetosiringon yang terlalu tinggi menyebabkan terjadinya nekrotik pada jaringan sehingga menyebabkan rendahnya efisiensi transformasi (Sah et al., 2014).

Hasil pengujian menunjukkan bahwa perbedaan konsentrasi asetosiringon mempengaruhi persentase pembentukan kalus, kalus tahan higromisin, efisiensi regenerasi dan transformasi (Gambar 3). Persentase pembentukan kalus menunjukkan hasil yang sama antara perlakuan tanpa dan penambahan $100 \mu \mathrm{M}$ AS, sedangkan pada perlakuan $200 \mu \mathrm{M}$ AS menunjukkan persentase pembentukan kalus yang lebih sedikit. Persentase kalus tahan higromisin, efisiensi regenerasi dan efisiensi transformasi menunjukkan hasil yang lebih tinggi pada konsentrasi asetosiringon $100 \mu \mathrm{M}$ dibandingkan pada media tanpa asetosiringon maupun pada konsentrasi asetosiringon $200 \mu \mathrm{M}$ (Gambar 3). Hal ini diduga bahwa asetosiringon berperan penting dalam proses transformasi tetapi pada konsentrasi yang tinggi $(200 \mu \mathrm{M})$ bersifat nekrotik pada selsel tanaman sehingga mempengaruhi pembentukan kalus. Pada konsentrasi $200 \mu \mathrm{M}$, perkembangan kalus terhambat dan pertumbuhan bakteri terlalu lebat menyelimuti kalus, sehingga kalus menjadi coklat (browning) dan akhirnya mati.

Menurut Tripathi et al. (2010) asetosiringon mempunyai peranan penting dalam proses transformasi. Konsentrasi asetosiringon yang digunakan pada transformasi genetik padi berbeda-beda tergantung genotipe padi yang digunakan. Konsentrasi asetosiringon $350 \mu \mathrm{M}$ menunjukkan frekuensi transformasi paling tinggi setelah analisis uji GUS pada padi Pusa Basmati, sedangkan efisiensi transformasi yang tinggi didapatkan pada konsentrasi asetosiringon 150 $\mu \mathrm{M}$ pada padi IR64 (Sahoo dan Tuteja, 2012). Efisiensi transformasi padi Fatmawati menunjukkan persentase yang lebih tinggi pada konsentrasi asetosiringon $100 \mu \mathrm{M}$ dibandingkan dengan asetosiringon $200 \mu \mathrm{M}$ maupun tanpa asetosiringon. Konsentrasi asetosiringon yang tinggi menyebabkan rendahnya frekuensi regenerasi karena berkaitan dengan efek nekrotik dari senyawa tersebut (Sah et al., 2014). 

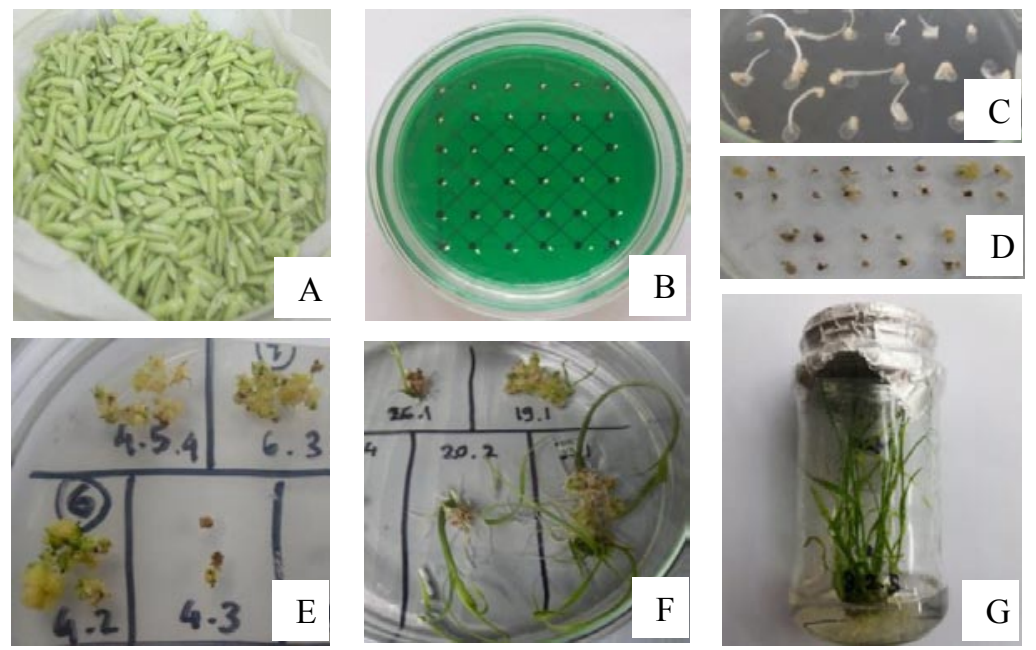

Gambar 2. Tahapan transformasi padi Fatmawati menggunakan eksplan embrio muda dengan perantaraan Agrobacterium. Eksplan biji muda padi yang akan diisolasi embrio mudanya (A), Embrio muda padi yang sudah diisolasi dan ditempatkan di media ko kultivasi (B), Embrio muda padi yang dikokultivasi dengan suspensi Agrobacterium, 7 hari di media ko-kultivasi (C), Kaluskalus transforman yang tumbuh di media seleksi ketiga dengan higromisin $30 \mathrm{mg} \mathrm{L}^{-1}$ (D), Kalus transforman dengan spot hijau (E), Tunas transforman yang tumbuh dari kalus yang tahan higromisin $(F)$, Planlet transforman di media perakaran $(\mathrm{G})$

\section{Pengaruh Perbedaan Konsentrasi Higromisin terhadap Kalus Padi Fatmawati Setelah Transformasi}

Persentase sel-sel pada kalus yang dapat ditransformasi (menerima DNA asing) relatif rendah, oleh karena itu sangatlah penting untuk menghambat perkembangan dari sesel non transforman (Zhu dan Wu, 2008). Penghambatan selsel non transforman dilakukan dengan antibiotik higromisin yang telah diketahui konsentrasi penghambatannya pada kalus padi Fatmawati yaitu pada konsentrasi 30, 40 dan $50 \mathrm{mg} \mathrm{L}^{-1}$ (Tabel 2). Ketiga konsentrasi higromisin tersebut digunakan untuk menyeleksi kalus-kalus transforman dan melihat pengaruhnya terhadap efisiensi transformasi. Hasil menunjukkan bahwa konsentrasi $30 \mathrm{mg} \mathrm{L}^{-1}$ higromisin menghasilkan efisiensi transformasi yang lebih tinggi yaitu sebesar $7.84 \%$ ketika dibandingkan dengan konsentrasi higromisin 40 dan $50 \mathrm{mg} \mathrm{L}^{-1}$ (Tabel 3).
Seleksi kalus transforman pada $30 \mathrm{mg} \mathrm{L}^{-1}$ higromisin menunjukkan bahwa semua tunas yang tahan ternyata juga mengandung gen hpt setelah dianalisis PCR (Tabel 3). Hal ini memberi indikasi bahwa higromisin $30 \mathrm{mg} \mathrm{L}^{-1}$ merupakan konsentrasi terbaik untuk menyeleksi kalus transforman. Tanaman yang diregenerasikan dari kalus yang menunjukkan positif dalam analisis molekulernya merupakan sistem seleksi yang efektif (Htwe et al., 2014). Konsentrasi higromisin yang lebih tinggi menunjukkan efisiensi transformasi yang lebih rendah diduga karena pada konsentrasi tersebut tingkat seleksi terhadap kalus transforman terjadi dengan ketat sehingga kemungkinan kalus-kalus yang mengandung gen ketahanan higromisin juga ikut terseleksi atau mati. Higromisin yang terlalu tinggi juga menghambat pertumbuhan dan perkembangan kaluskalus transforman sehingga pada akhirnya kalus tersebut mati. Tran dan Mishra (2015) menyatakan bahwa adanya
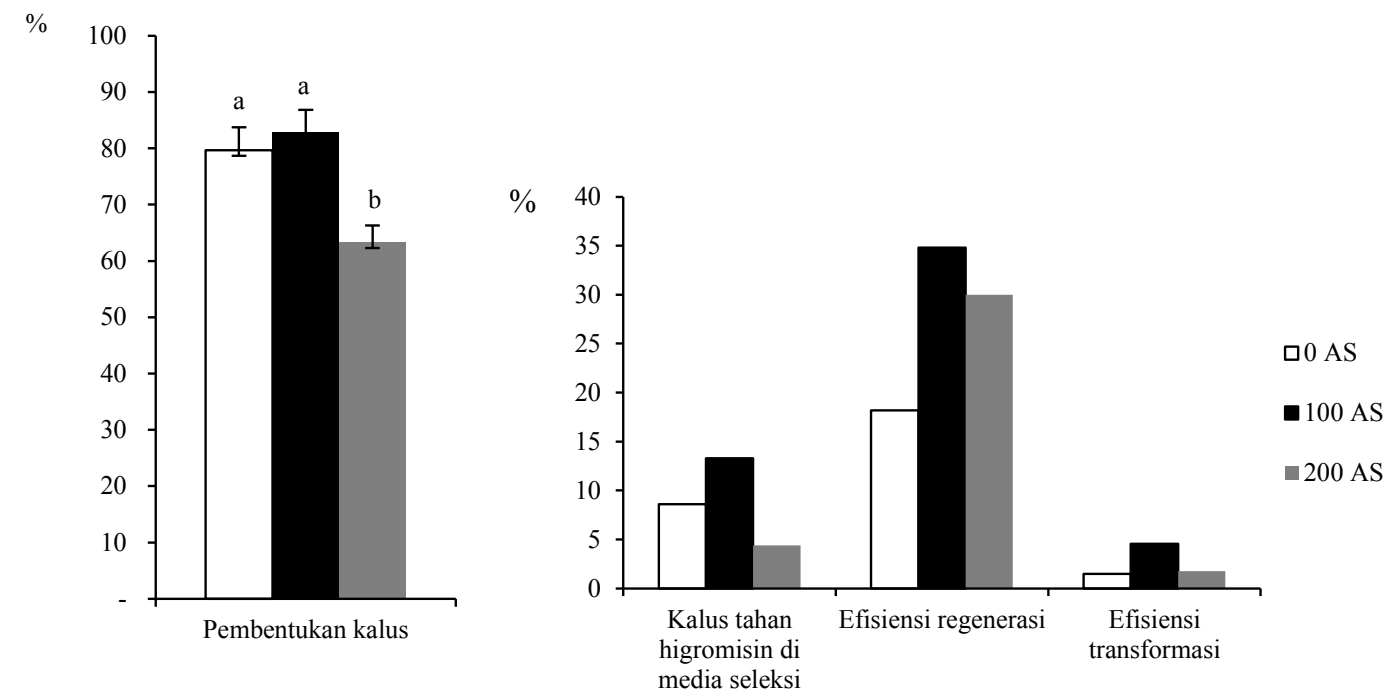

Gambar 3. Pengaruh Asetosiringon (AS) terhadap persentase pembentukan kalus, kalus yang tahan higromisin di media seleksi, efisiensi regenerasi dan efisiensi transformasi 
Tabel 3. Pengaruh perbedaan konsentrasi higromisin untuk seleksi kalus terhadap efisiensi regenerasi dan transformasi

\begin{tabular}{lccccccc}
\hline $\begin{array}{l}\text { Konsentrasi } \\
\text { higromisin } \\
\left(\mathrm{mg} \mathrm{L}^{-1}\right)\end{array}$ & $\begin{array}{c}\text { Jumlah } \\
\text { EM yang } \\
\text { ditransformasi }\end{array}$ & $\begin{array}{c}\text { Jumlah } \\
\text { kalus tahan } \\
\text { higromisin } \\
(\mathrm{A})\end{array}$ & $\begin{array}{c}\text { Jumlah kalus } \\
\text { dengan spot } \\
\text { hijau }\end{array}$ & $\begin{array}{c}\text { Jumlah kalus } \\
\text { beregenerasi/ } \\
\text { galur } \\
\text { independen (D) }\end{array}$ & $\begin{array}{c}\text { Efisiensi } \\
\text { regenerasi } \\
(\%)^{2)}\end{array}$ & $\begin{array}{c}\text { Jumlah } \\
\text { galur/planlet } \\
\text { positif PCR } \\
(\mathrm{C})\end{array}$ & $\begin{array}{c}\text { Efisiensi } \\
\text { transformasi } \\
(\%)^{3)}\end{array}$ \\
\hline 30 & 153 & 43 & 36 & 12 & 27.9 & 12 & 7.84 \\
40 & 98 & 12 & 9 & 2 & 16.7 & 2 & 2.04 \\
50 & 120 & 10 & 8 & 1 & 10.0 & 1 & 0.83 \\
\hline
\end{tabular}

Keterangan: ${ }^{1}$ Embrio muda, ${ }^{2}$ Dihitung dari perbandingan antara jumlah kalus yang beregenerasi dengan jumlah, kalus yang tahan higromisin (D/B) dikalikan 100\%, ${ }^{3}$ Dihitung dari perbandingan antara jumlah planlet dengan jumlah EM yang ditransformasi (C/A) dikalikan $100 \%$

antibiotik pada level yang tinggi tidak hanya mematikan sel-sel non transforman tetapi juga akan menghambat pertumbuhan sel-sel transforman sehingga akan mempengaruhi regenerasinya. Penelitian Mulyaningsih et al. (2010) menggunakan konsentrasi higromisin $25 \mathrm{mg} \mathrm{L}^{-1}$ untuk menyeleksi kalus-kalus padi Batutegi dan Kasalath. Hal ini memberi indikasi bahwa perbedaan konsentrasi higromisin untuk menyeleksi kalus transforman diduga juga bersifat tergantung genotipe.

\section{Analisis Molekuler Galur Padi Transgenik dengan Menggunakan Teknik PCR}

Galur-galur putatif padi transgenik yang dihasilkan dianalisis secara molekuler dengan teknik PCR untuk mengetahui apakah konstruk pCAMBIA1301 berhasil diintroduksikan ke padi Fatmawati. Tanaman padi putatif transgenik yang dihasilkan pada penelitian ini ialah 14 galur. Ke-14 galur tersebut kemudian diisolasi DNAnya dan dilakukan analisis PCR dengan menggunakan primer untuk gen hpt.

Hasil analisis PCR dari 14 galur tanaman padi Fatmawati putatif transgenik yang dihasilkan dari transformasi, menunjukkan positif mengandung gen $h p t$ (Gambar 4). Hasil positif ditunjukkan dengan terbentuknya amplikon dari gen $h p t$ yang berukuran $500 \mathrm{bp}$, ukuran ini sama dengan amplikon dari kontrol plasmid CAMBIA1301. Hasil uji PCR menunjukkan bahwa semua planlet yang lolos seleksi higromisin dengan konsentrasi $30-50 \mathrm{mg} \mathrm{L}^{-1}$ ternyata juga positif mengandung gen $h p t$ yang terdapat pada konstruk pCAMBIA1301.

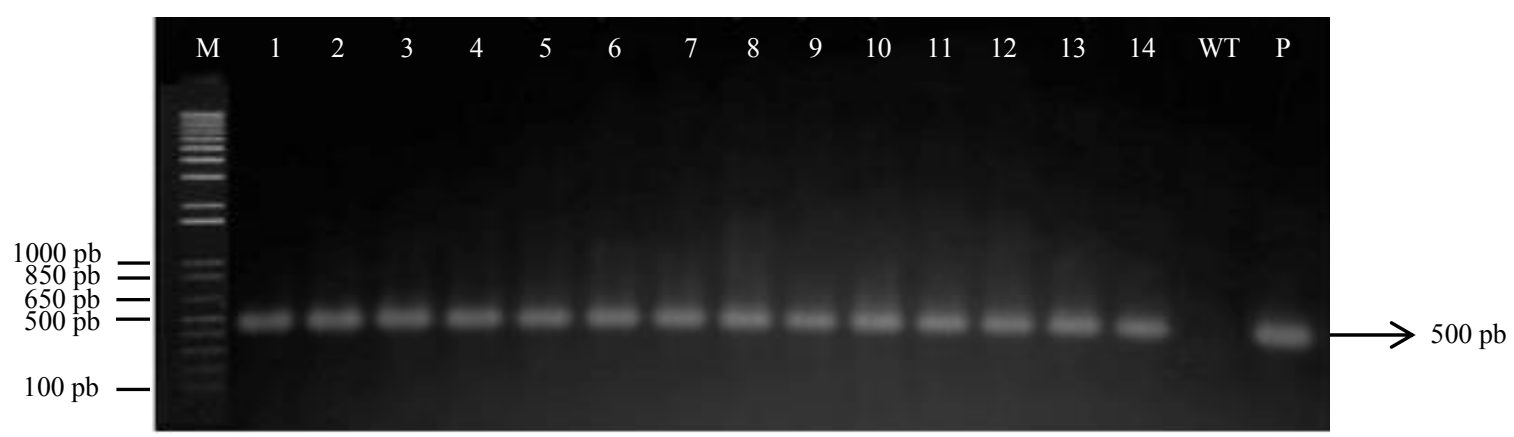

Gambar 4. Hasil analisis PCR menggunakan primer gen hpt dari galur-galur tanaman padi Fatmawati putatif transgenik. 1 kb ladder (M), galur padi Fatmawati putatif transgenik (1-14), kontrol wild type (WT), kontrol plasmid CAMBIA1301 (P)

\section{KESIMPULAN}

Varietas padi Fatmawati dapat ditransformasi dengan perantaraan Agrobacterium menggunakan eksplan berupa embrio muda. Penggunaan asetosiringon $100 \mu \mathrm{M}$ pada media kokultivasi dan higromisin $30 \mathrm{mg} \mathrm{L}^{-1}$ untuk menyeleksi kalus transforman merupakan konsentrasi yang optimal untuk transformasi genetik padi Fatmawati menggunakan A. tumefaciens dengan efisiensi transformasi sebesar 7.84\%. Metode transformasi genetik padi Fatmawati ini dapat digunakan sebagai acuan dalam transformasi selanjutnya dengan menggunakan gen target.

\section{DAFTAR PUSTAKA}

Abdullah, B., S. Tjokrowijoyo, Sularjo. 2008. Perkembangan dan prospek perakitan padi tipe baru di Indonesia. J. Litbang Pertanian 27:1-5.

Apriana, A., A. Sisharmini, W. Enggarini, Sudarsono, N. Khumaida, K.R. Trijatmiko. 2011. Introduksi konstruk over ekspresi kandidat gen OsWRKY76 melalui Agrobacterium tumefaciens pada tanaman padi Nipponbare. J. Agrobiogen 7:19-27. 
Chilton, M.D., T.C. Currier, S.K. Farrand, A.J. Bendich, M.P. Gordon, E.W. Nester. 1974. Agrobacterium DNA and PS8 bacteriophage DNA not detected in crown gall tumors. Proc. Natl. Acad. Sci. USA. 71:3672-3676.

Chu, C.C., C.C. Wang, C.S. Sun, C. Hus, K.C. Yin, C.Y. Chu. 1975. Establishment of an efficient medium for anther culture of rice through comparative experiments on the nitrogen sources. Sci. Sinica 18:659-668.

Cho, A.R., D.K. Lee, K.M. Kim. 2015. High frequency plant regeneration from transgenic rice expressing Arabidopsis thaliana bax inhibitor (At BI-1) tissue cultures. J. Plant Biotechnol. 42:83-87.

Gamborg, O.L., R.A. Miller, K. Ojima. 1968. Nutrient requirement of suspensions cultures of soybean root cells. Exp. Cell Res. 50:151.

Hiei, Y., T. Komari. 2008. Agrobacterium-mediated transformation of rice using immature embryo or calli induced from mature seed. Nat. Protoc. 3:824834.

Hiei, Y., Y. Ishida. T, T. Komari. 2014. Progress in cereal transformation technology mediated by Agrobacterium tumefaciens. Front Plant Sci. 5:1-11.

Htwe, W.W., H.C. Ling, F.Q. Zaman, M. Maziah. 2014. Plant genetic transformation efficiency of selected Malaysian rice based on selection marker gen ( $h p t I I)$. Pak. J. Biol. Sci. 17:472-481.

Jia, Y., X. Yao, M. Zhao, Q. Zhao, Y. Du, C. Yu, F. Xie. 2015. Comparison of soybean transformation efficiency and plant factors affecting transformation during the Agrobacterium infection process. Int. J. Mol. Sci. 16:18522-18543.

Mulyaningsih E.S., H. Aswidinnoor, D. Sopandie, P.B.F. Ouwerkerk, I.H. Slamet- Loedin. 2010. Transformasi padi indica kultivar Batutegi dan Kasalath dengan gen regulator HD-Zip untuk perakitan varietas toleran kekeringan. J. Agron. Indonesia 38:1-7.

Murray, M.G., W.F. Thompson. 1980. Rapid isolation of high-molecular-weight plant DNA. Nucleic Acid Res. 8:4321-4325.

Nakano, Y. 2017. Effect of acetosiringone on Agrobacteriummediated transformation of Eustoma grandiflorum leaf disks. JARQ. 51:351-355.

Nyaboga, E., J.N. Tripathi, R. Manoharan, L. Tripathi. 2014. Agrobacterium-mediated genetic transformation of yam (Dioscorea rotundata) : an important tool for functional study of genes and crop improvement. Front. Plant Sci. doi:10.3389/fpls.2014.00463.

Ozawa, K. 2009. Establishment of a high efficiency Agrobacterium mediated transformation system of rice (Oryza sativa L.). Plant Sci. 176:522-527.

Sahoo, K.K., A.K. Tripathi, A. Pareek, S.K. Sopory, S.L.S. Pareek. 2011. An improved protocol for efficient transformation and regeneration of diverse indica rice cultivar. Plant Methods 7:49.

Sahoo, R.K., Tuteja, N. 2012. Development of Agrobacterium-mediated transformation technology for mature seed-derived callus tissue of Indica rice cultivar IR64. GM Crop and Food Biotechnol. in Agricult. Food Chain 3:123-128.

Sah, S.K., A. Kaur, G. Kaur, G.S. Cheema. 2014. Genetic transformation of rice: problem, progress and prospects. J. Rice Res. 3:132.

Saika, H., S. Toki. 2010. Mature seed derived callus of the model indica rice variety Kasalath is highly competent in Agrobacterium mediated transformation. Plant Cell Rep. 29:1351-1364.

Slamet-Loedin, I.H., P. Chadha-Mohanty, L. Torrizo. 2014. Agrobacterium-mediated transformation: rice transformation. Methods Mol. Biol. 1099:261-71.

Tie, W., F. Zhao, L. Wang, W. Xie, H. Chen, X. Li, Y. Lin. 2012. Reason for lower transformation efficiency in indica rice using Agrobacterium tumefaciensmediated transformation : lessons from transformation assays and genome-wide expression profiling. Plant Mol. Biol. 78:1-18.

Tran, N.T., N.S. Mishra. 2015. Effect of antibiotic on callus regeneration during transformation of IR64 rice. Biotechnol. Rep. 7:143-149.

Tripathi, R.M., H.S. Bisht, R.P. Singh. 2010. Effect of acetosyringone and callus age on transformation for scutellum-derived callus of rice. Int. J. Pharma Bio Sci. 1:163-171.

Vennapusa, A.R., R.S. Vemanna, R. Reddy, K.C. Babitha, K. Kiranmai, A. Nareskhumar, C. Sudhakar. 2015. An efficient callus induction and regeneration protocol for a drought tolerant rice indica genotype AC39020. J. Plant Sci. 3:248-254.

Zhu, Z., R. Wu. 2008. Regeneration of transgenic rice plants using high salt for selection without the need for antibiotics or herbicides. Plant Sci. 174:519-523. 